\title{
Junior High School Students' Understanding of The Nature of Science
}

\author{
Iqbal Habiby ${ }^{1^{*}}$, Hernani ${ }^{2}$, Tri Suwandi ${ }^{3}$ \\ ${ }^{1}$ Science Education, School of Postgraduate Studies, Universitas Pendidikan Indonesia, Indonesia \\ ${ }^{2}$ Department of Chemistry Education, Universitas Pendidikan Indonesia, Indonesia \\ ${ }^{3}$ Department of Biology Education, Universitas Pendidikan Indonesia, Indonesia \\ *Corresponding e-mail: iqbalhabiby@upi.edu
}

Received: 09 March 2020

Accepted: 20 June 2020

Published: 17 August 2020

Abstract: Junior high school students' understanding of the nature of science. Objective: The purpose of this research is to explore the junior high school students' understanding of nature of science (NOS). Methods: The survey in this research was conducted in 8th grade as many as 80 students from three schools in East Prabumulih Sub-District, South Sumatera Province, Indonesia, which was determined by stratified random sampling technique. Students' understanding of 7 aspects of NOS was measured using a questionnaire containing 35 items consisting of 4 Likert scale statements (scale 1-5) and 1 question open-ended responses to each aspect of NOS. Findings: The results showed that students' understanding of NOS is still inadequate. The students' understanding of NOS that inadequate shown through by the small percentage of the informed view category on all aspects of the NOS measured, both Likert scale items and open-ended responses. Conclusion: These findings emphasize the need for learning to improve understanding of NOS for students.

Keywords: nature of science, survey method, students understanding.

Abstrak: Pemahaman siswa SMP mengenai hakikat sains. Tujuan: Tujuan penelitian ini adalah untuk mengeksplorasi pemahaman siswa SMP mengenai hakikat sains (NOS). Metode: Survei pada penelitian ini dilakukan kepada siswa kelas 8 sebanyak 80 siswa dari tiga sekolah di Kecamatan Prabumulih Timur, Provinsi Sumatera Selatan, Indonesia, yang ditentukan dengan teknik stratified random sampling. Pemahaman siswa pada 7 aspek NOS diukur menggunakan kuesioner berisi 35 item yang terdiri atas 4 pernyataan skala likert (skala 1-5) dan 1 pertanyaan open-ended responses tiap aspek NOS. Temuan: Hasil menunjukkan bahwa pemahaman siswa mengenai NOS masih belum baik. Pemahaman NOS siswa yang masih belum baik ditunjukkan melalui persentase kategori informed view pada semua aspek NOS yang diukur sangat kecil, baik item skala likert maupun open-ended responses. Kesimpulan: Temuan ini menekankan perlunya dilakukan pembelajaran yang meningkatkan pemahaman NOS pada siswa.

Kata kunci: hakikat sains, metode survei, pemahaman siswa.

\section{To cite this article:}

Habiby, I., Hernani, \& Suwandi, T. (2020). Junior High School Students' Understanding of The Nature of Science. Jurnal Pendidikan Progresif, 10(2), 154-161. doi: 10.23960/jpp.v10.i2.202001. 


\section{- INTRODUCTION}

The purpose of science education nowadays is to form students who have scientific literacy (Khishfe, Alshaya, BouJaoude, Mansour, \& Alrudiyan, 2017; Lederman, Lederman, \& Antink, 2013; Holbrook \& Rannikmae, 2007). This objective emphasizes the importance of students' conceptual understanding of ideas in science, which are cause and effect, structure and function, and cycles. These ideas are considered to make students reach beyond just memorizing and understanding scientific content (Lederman, Lederman, \& Antink, 2013). Hurd (1998) stated that fostering scientific literacy for students aims to enable students to be able to choose, organize, and utilize scientific knowledge in everyday life. Scientific literacy will help individuals living in the present to face new knowledge and products from science and technology and socio-scientific issues (Mun et al., 2013).

Regarding the situation of Indonesian science education related to the objectives of science education, we need to look at the curriculum documents in Indonesia. In the appendix of the Minister of Education and Culture Regulation (also known as Permendikbud in Indonesia) number 20 of 2016 about Competency Standards for Primary and Secondary Education Graduates in Indonesia, particularly in the dimension of knowledge for junior high school students must deal with "Having factual, conceptual, procedural, and metacognitive knowledge at a simple technical and specific level regarding with: (1) science, (2) technology, (3) art, and (4) culture. Able to link the knowledge in the context of themself, family, school, community, and the surrounding environment, nation, country, and regional sector" (Regulation of the Minister of Education and Culture, 2016). The contents of the Permendikbud appendix describe that science education in Indonesia has directed its educational goals towards science literacy.

Nevertheless, reality shows that the scientific literacy achievements of Indonesian students are still low. Based on the results of PISA 2009-2015, the scientific literacy of Indonesian students shows inappropriate results. The average achievement score of Indonesian students' scientific literacy is below the average OECD score (Wati, Sinaga, \& Priyandoko, 2017). Moreover, there was a decrease in the achievement of scientific literacy at PISA 2018, which score of 396 from the OECD average score of 489 (OECD, 2019). The low achievement of scientific literacy is presumably due to the students' low understanding of the nature of science (NOS).

The core of scientific literacy is related to the understanding of NOS (Khishfe \& Lederman, 2007). Student characteristics that have scientific literacy are directly related to the NOS components (Akerson, Carter, Pongsanon, \& Nargund-Joshi, 2019; Khishfe, 2017; Das, Faikhamta \& Punsuvon, 2017). According to Lederman, NOS is defined typically refers to the epistemology of science, which is science as a way of knowing, or the values and beliefs inherent to the development of scientific knowledge (Lederman, Lederman, \& Antink, 2013). Currently, there is no official definition of NOS among scientists. However, they believe in the existence and urgency of NOS in education. NOS consists of certain aspects, such as observation and inference, scientific theories and laws, scientific methods, imagination and creativity, subjective, social and cultural, tentative, and empirical (Lederman, Lederman, \& Antink, 2013; Lederman \& AbdEl-Khalick, 1998; Maeng, Bell, Clair, Gonczi, \& Whitworth, 2018).

An understanding of NOS allows students to understand the nature of the various 
facets of the formation of scientific knowledge (Khishfe, 2012), thus making students aware that scientific knowledge is not merely scientific theory and law. It will develop a deep understanding of how the students' scientific knowledge is generated and how the use of NOS understanding addresses the status of knowledge. It is intended that students can make decisions based on information about real-world science problems, both personal and socio-scientific (Lederman, Lederman, \& Antink, 2013; Khishfe, 2012; Herman, Newton, Owens, Oertli, \& Zangori, 2019), afterward students will be able to play more active and effective roles in society (Khishfe, 2012).

Previous researches in various countries measured students' understanding of NOS at the high-grade level and on a large scale (Das, Faikhamta, \& Punsuvon, 2017; Dogan \& AbdEl-Khalick, 2008; Ryan \& Aikenhead, 1992). In this researches, it is known that most students have an inadequate understanding of NOS. On the other hand, research that improves students' understanding of NOS shows that NOS understanding will help the acquisition of scientific content (Michel \& Neumann, 2016), decision making on socioscientific issues (Khishfe, 2012), and make better arguments (Khishfe, Alshaya, BouJaoude, Mansour, \& Alrudiyan, 2017; Khishfe, 2014). It means that an adequate understanding of NOS will improve other abilities of students. Meanwhile, research on students' understanding of NOS in Indonesia is still limited. Besides, follow-up and implications in learning science about the results of analyzes of NOS understanding have not been widely reported. Seeing this situation, it is felt necessary to conduct research related to students' understanding of NOS. Therefore, this research will report the analysis of NOS understanding of junior high school students in the scope of one small area as a consideration in developing learning strategies to facilitate students developing their understanding of NOS. This research aims to explore student understanding of NOS by following the research question "what is students" understanding of NOS in $8^{\text {th }}$ grade junior high school?".

\section{METHOD \\ Research Design}

This research uses a survey method in which the researcher intends to know students' understanding of NOS. The main way of gathering information using the survey method is through asking questions by interview, questionnaires, etc. (Fraenkel, Wallen, \& Hyun, 2012). The responses given by each research subject are coded into the understanding of NOS for analysis to describe the research subject's understanding of NOS.

\section{Research subject}

The subjects in this research were $8^{\text {th }}$ grade junior high school students in Prabumulih City. A total of 80 students from three different junior high schools participated in this research. The junior high schools chosen for the research are the junior high schools in the East Prabumulih SubDistrict because of the number of junior high schools in this sub-district higher than others. Schools selected using a stratified random sampling technique where schools are grouped according to the type of accreditation and then randomly selected schools that will be used for research.

\section{Data collection tools}

Data were collected from research subjects using the Student Understanding of Science and Scientific Inquiry (SUSSI) instrument from previous researches that had been validated with high internal reliability values (Das, 
Faikhamta, \& Punsuvon, 2017). The instrument in the form of a questionnaire consisting of two parts, the Likert scale items in the first section and open-ended responses in the second section. This instrument measures seven aspects of NOS, such as observation and inference, tentative, scientific theories and laws, social and cultural influences, creativity and imagination, scientific methods, and empirical.

\section{Data analysis technique}

The data in this research were analyzed statistically descriptive. Student responses to Likert scale statements and open-ended responses are grouped according to a certain category, the percentage of each category is calculated, and tabulated in the form of a percentage of students' NOS understanding. Finally, the results shown in the table are interpreted in the form of narrative sentences.
The Likert scale items have a score range of 1-5 and consist of four statements, both positive and negative statements, on each aspect of the NOS measured. Scoring for positive statements has the highest score on a scale of 5 (strongly agree) and scoring for negative statements has the highest score on a scale of 1 (strongly disagree). Classification of students understanding of NOS using a Likert scale follow the guidelines of Liang (2008) in Das, Faikhamta, and Punsuvon (2017) as shown in the table1.

Open-ended responses consist of a question on each aspect of NOS. The scoring guide on the open-ended responses divided into 4 categories, which are non-classifiable ( 0 ), naive (1), transitional (2), and informed (3). Explanations in classifying student answers for each category using open-ended responses follow the guidelines from Liang (2009) in Das, Faikhamta, and Punsuvon (2017) as shown in the table 2 .

Table 1. Guidelines for Likert scale items scoring

\begin{tabular}{lll}
\hline \multicolumn{1}{c}{ Naove View } & \multicolumn{1}{c}{ Transitional View } & \multicolumn{1}{c}{ Informed View } \\
\hline $\begin{array}{l}\text { If none of the four responses } \\
\text { scored more than three. }\end{array}$ & If one or more than one (but not all) of the four & If all of the four responses \\
responses were more, equal to or less than three. & received more than 3. \\
\hline
\end{tabular}

Table 2. Guidelines for open-ended responses scoring

\begin{tabular}{|c|c|c|c|}
\hline Non-Classifiable & Naive View & Transitional View & Informed View \\
\hline $\begin{array}{l}\text { If there was no response or } \\
\text { students stated that they did } \\
\text { not know the answer or the } \\
\text { response could not be } \\
\text { classified based on the rubric } \\
\text { descriptions. }\end{array}$ & $\begin{array}{l}\text { If there were } \\
\text { misconceptions or made } \\
\text { self-contradicting } \\
\text { statements. }\end{array}$ & $\begin{array}{l}\text { If the responses showed } \\
\text { partial informed views } \\
\text { without any justification or } \\
\text { if the students provided } \\
\text { unrelated examples. }\end{array}$ & $\begin{array}{l}\text { If the responses } \\
\text { were consistent to } \\
\text { the contemporary } \\
\text { thoughts on each } \\
\text { aspect of NOS. }\end{array}$ \\
\hline
\end{tabular}

Table 3. Percentage of students' NOS understanding in the Likert scale items

\begin{tabular}{lccc}
\hline \multicolumn{1}{c}{ Aspects of NOS } & Naive (\%) & Transitional (\%) & Informed (\%) \\
\hline Observation and Inference & 0 & 98.75 & 1.25 \\
Tentativeness & 0 & 100 & 0 \\
Scientific Theories and Laws & 0 & 86.25 & 13.75 \\
Social and Cultural Embeddedness & 2.5 & 97.5 & 0 \\
Creativity and Imagination & 11.25 & 83.75 & 5 \\
Scientific Method & 2.5 & 97.5 & 0 \\
Empirical Nature of Scientific Knowledge & 5 & 82.5 & 12.5 \\
\hline
\end{tabular}


Table 4. Percentage of students' NOS understanding in open-ended responses

\begin{tabular}{lcccc}
\hline \multicolumn{1}{c}{ Aspects of NOS } & $\begin{array}{c}\text { Non-Classifiable } \\
(\mathbf{\%})\end{array}$ & Naive (\%) & $\begin{array}{c}\text { Transitional } \\
\mathbf{( \% )}\end{array}$ & $\begin{array}{c}\text { Informed } \\
(\mathbf{\%})\end{array}$ \\
\hline Observation and Inference & 41.25 & 18.75 & 40 & 0 \\
Tentativeness & 46.25 & 22.50 & 31.25 & 0 \\
Scientific Theories and Laws & 47.50 & 28.75 & 23.75 & 0 \\
Social and Cultural & 35 & 46.25 & 18.75 & 0 \\
Embeddedness & & & & \\
Creativity and Imagination & 43.75 & 22.50 & 33.75 & 0 \\
Scientific Method & 80 & 12.50 & 7.50 & 0 \\
Empirical Nature of Scientific & 63.75 & 36.25 & 0 & 0 \\
Knowledge & & & & \\
\hline
\end{tabular}

\section{RESULTS AND DISCUSSION}

A total of 80 students who participated in this research filled out a questionnaire consisting of two parts, which are Likert scale items and open-ended responses. Based on the trials instrument, the results obtained as shown in tables 3 and 4.

Table 3 showed that students' NOS understanding on the Likert scale items was mostly in the transitional view. This was shown from the percentage of students' understanding of NOS in all aspects valued more than $80 \%$ in the transitional view with tentative aspects having a perfect score, $100 \%$. Students' understanding of NOS in the naïve view was in four aspects with aspects of creativity and imagination being aspects with the greater naïve view than other aspects. Meanwhile, students' understanding of NOS in the informed view was in four aspects with aspects of scientific theories and laws being aspects with a greater informed view than other aspects. The findings of this research are in line with research conducted by Das, Faikhamta, and Punsuvon (2017) who found that most students held transitional views. This is likely due to NOS not being explicitly included in the educational curriculum framework. NOS is considered to obtained automatically by students through an inquiry-oriented approach in science learning. In addition, the lack of a teacher's role in facilitating students to understand the way in which scientific concepts are generated is also linked as a contributing factor to this.
Table 4 showed that students' understanding of NOS in open-ended responses was more dominated in the non-classifiable view. This was indicated by the percentage of students' understanding of NOS at this view having a greater percentage than the other view, especially in the aspect of the scientific method which reaches a percentage of $80 \%$. Students' understanding of NOS in the naïve view was greatest in the aspect of social and cultural embeddedness with a percentage of $46.25 \%$. As for the transitional view, the highest score was in the observation and inference aspects with a percentage of $40 \%$. Meanwhile, none of the students held an informed view of this section. This result was in line with findings of Sangsa-ard, Thathong, and Chapoo (2014) who find that students held more naïve views and none held informed views. According to them, this inadequate result is likely due to NOS taught implicitly. NOS that taught implicitly makes students not know about NOS.

Based on the students' answers given to open-ended responses, at the non-classifiable view, most students wrote, "I don't know" and there were some students who not write answer all the questions. At the naïve view, some students gave misconception answers to tentative aspects, such as "scientific theory cannot change because it is already a natural determination". At the transitional view, students were able to answer by following the thoughts of experts but they have not been able to provide adequate explanations 
of these thoughts and provide examples related to these NOS aspects. Examples of student answers at the transitional view for tentative aspects, which students wrote, "scientific theories can change because all scientists have different theories and different brains".

The results obtained in this research have a difference in the research conducted by previous researchers (Das, Faikhamta, \& Punsuvon, 2017). The difference is seen in the open-ended responses of their research that only the scientific theories and laws aspects have a percentage of 0 at the informed. In this research, none of the students held an informed view of all aspects of NOS in open-ended responses. This difference might be due to students in the East Prabumulih sub-district who have never gained knowledge about NOS, both from the teacher and from other sources.

The results of this research reveal that the student acceptance of NOS aspects shown on the Likert scale statement is in the middle category, having a score ranging from 3 to 5 on 1 to 3 statements about NOS aspects. However, when students' knowledge about NOS aspects is explored using open-ended responses, it turns out that the student's knowledge dominated at the non-classifiable view. These findings indicate the need to teach students knowledge about NOS. Previous researchers' findings inform that teaching NOS to students can use an explicit-reflective approach (Khishfe \& Abd-El-Khalick, 2002). Teaching NOS using an explicit-reflective approach allows students to understand NOS because NOS aspects are taught directly through mentioning NOS aspects explicitly in learning objectives, the teacher gives questions related to NOS aspects, students are allowed to discuss and reflect on NOS aspects, and also reflect the results of scientific investigations they do in learning (Akerson, Carter, Pongsanon, \& Nargund-Joshi, 2019).
Teaching NOS to students can be given since students are still at a low-level class (Akerson, Buck, Donelly, Nargund-Joshi, \& Weiland, 2011). There is no age limit in teaching NOS to students, even though they are still in kindergarten. It is better because teaching NOS early on will foster understanding of NOS and embed early on scientific literacy in students. Hopefully, students will be able to use their scientific knowledge to solve various problems related to science in their daily lives in the future.

\section{- CONCLUSION}

The results obtained in the research indicate that students' understanding of NOS is still inadequate. This was evidenced by the two parts of the questionnaire which showed a low percentage of students' informed views regarding NOS aspects. Although students' acceptance related to NOS aspects is at the transitional view, students' knowledge of NOS aspects is dominated at the non-classifiable view. These results indicate the need for aspects of NOS to be taught by teachers in science learning.

This research has limitations where students involved in the research were given a questionnaire at different times. Questionnaires were given to two schools before the final exam and one school was given questionnaires after the final exam. The time difference is due to obstacles in obtaining permission to distribute questionnaires to school, so the authors looked for alternative schools that were willing to.

The recommendation for future researchers is to choose the perfect timing for conducting the research. The research should be done in the middle of the semester and taking care of licensing to the intended school was completed a few weeks before the research. This is to avoid things that are not desirable. The next recommendation is that teachers need to teach NOS to students. Teaching NOS can be done early on as a provision to form students who have scientific 
literacy. For junior high school level, NOS can be taught since the seventh grade did previous researchers (Khishfe, 2014). Previous researches have shown that NOS is suitable to be taught through an explicit-reflective approach. The explicit-reflective approach taken can use context or without context (specifically teaching aspects of NOS through certain activities) (Khishfe \& Lederman, 2007). Using one or both types of explicit-reflective approaches will very helpful in giving students a good understanding of NOS.

\section{- ACKNOWLEDGMENT}

The author would like to thanks all the students who participated in this research. Moreover, the author would also thank the headmasters who had given a chance the author to research in their schools. Further, the author would like to thanks the supervisors who had guided the process of writing this article. Hopeful this article is fruitful and useful for readers and other researchers.

\section{REFERENCES}

Akerson, V. L., Carter, I., Pongsanon, K., \& Nargund-Joshi, V. (2019). Teaching and Learning Nature of Science in Elementary Classrooms: Research-Based Strategies for Practical Implementation. Science \& Education, 28, 391-411.

Akerson, V. L., Buck, G. A., Donelly, L. A., Nargund-Joshi, V., \& Weiland, I. S. (2011). The Importance of Teaching and Learning Nature of Science in the Early Childhood Years. Journal of Science Education and Technology, 20, 537-549.

Das, P. M., Faikhamta, C., \& Punsuvon, V. (2017). Bhutanese Students' Views of Nature of Science: a Case Study of Culturally Rich Country. Research in Science Education, 49(2), 391-412.

Dogan, N., \& Abd-El-Khalick, F. (2008). Turkish Grade 10 Students' and Science
Teachers' Conceptions of Nature of Science: A National Study. Journal of Research in Science Teaching, 45(10), 1083-1112.

Fraenkel, J. R., Wallen, N. E., \& Hyun, H. H. (2012). How to Design and Evaluate Research in Education. New York: McGram-Hill.

Herman, B. C., Newton, M. H., Owens, D. C., Oertli, R. T., \& Zangori, L. A. (2019). Exploring the Complexity of Students' Scientific Explanations and Associated Nature of Science Views Within a PlaceBased Socioscientific Issue Context. Science \& Education, 28, 329-366.

Holbrook, J., \& Rannikmae, M. (2007). The Nature of Science Education for Enhancing Scientific Literacy. International Journal of Science Education, 29(11), 1347-1362.

Hurd, P. D. (1998). Scientific Literacy : New Minds for a Changing World. Science Education, 82(3), 407-416.

Khishfe, R., Alshaya, F. S., BouJaoude, S., Mansour, N., \& Alrudiyan, K. I. (2017). Students' Understandings of Nature of Science and Their Arguments in the Context of Four Socio-Scientific Issues. International Journal of Science Education, 39(3), 299-334.

Khishfe, R. (2017). Consistency of Nature of Science Views Across Scientific and Socio-Scientific Contexts. International Journal of Science Education, 39(4), 403-432.

Khishfe, R. (2014). Explicit Nature of Science and Argumentation Instruction in the Context of Socioscientific Issues: An effect on student learning and transfer. International Journal of Science Education, 36(6), 974-1016.

Khishfe, R. (2012). Nature of Science and Decision-Making. International Journal 
of Science Education, 34(1), 67-100.

Khishfe, R., \& Lederman, N. (2007). Relationship between Instructional Context and Views of Nature of Science. International Journal of Science Education, 29(8), 939-961.

Khishfe, R., \& Abd-El-Khalick, F. (2002). Influence of Explicit and Reflective versus Implicit Inquiry-Oriented Instructionon Sixth Graders'Views of Nature of Science. Journal of Research in Science Teaching, 39(7), 551-578.

Lederman, N. G., Lederman, J. S., \& Antink, A. (2013). Nature of Science and Scientific Inquiry as Contexts for the Learning of Science and Achievement of Scientific Literacy. International Journal of Education in Mathematics, Science and Technology, 1(3), 138-147.

Lederman, N., \& Abd-El-khalick, F. (1998). Avoiding De-Natured Science: Activities that Promote Understanding of the Nature of Science. In: McComas W. F. (eds) The Nature of Science Education. Science and Technology Education Library, 83-126. Maeng, J. L., Bell, R. L., Clair, S. T., Gonczi, A. L., \& Whitworth, B. A. (2018). Supporting Elementary Teachers' Enactment of Nature of Science Instruction: ARandomized Controlled Trial.International Journal of Science Education, 1-20.

Mun, K., Lee, H., Kim, S., Choi, K., Choi, S., \& Krajcik, J. (2013). Cross-Cultural
Comparison of Perceptions on the Global Scientific Literacy With Australian, Chinese, and Korean Middle School Students. International Journal of Science and Mathematics Education, 13(2), 437-465.

OECD. (2019). PISA 2018 Results: Snapshot of Students' Performance in Reading, Mathematics, and Science. Retrieved 15 January, 2020 from https://www.oecd.org/ pisa/PISA-results_ENGLISH.png.

Regulation of the Minister of Education and Culture. (2016). Copy of Appendix to the Minister of Education and Culture Regulation Number 20 in 2016 Concerning Competency Standards for Primary and Secondary Education Graduates. Jakarta: The Minister of Education and Culture.

Ryan, A. G., \& Aikenhead, G. S. (1992). Students' Preconceptions about the Epistemology of Science. Science Education, 76(6), 559-580.

Sangsa-ard, R., Thathong, K., \& Chapoo, S. (2014). Examining Grade 9 Students' Conceptions of the Nature of Science. Procedia - Social and Behavioral Sciences, 116, 382-388.

Wati, F., Sinaga, P., \& Priyandoko, D. (2017). Science Literacy: How do High School Student Solve PISA Test Items?. Journal of Physics: Conference Series, 895(1), 1-6. 